\title{
Study of Descendent Course of Buccal Nerve in Adults Individuals
}

\author{
Estudio del Trayecto Descendente del Nervio Bucal en Individuos Adultos
}

Nilton Alves

\begin{abstract}
ALVES, N. Study of descendent course of buccal nerve in adults individuals. Int. J. Morphol., 27(2):295-298, 2009.
SUMMARY: The knowledge of the buccal nerve anatomy is of fundamental importance not only for the anesthesia but also for a safe intervention in the retromolar area. The aim of this work was to study its trajectory, in the area where it is related to the anterior margin of the ramus of the mandible, therefore providing important data for a safe intervention in the region. In this study we used 10 hemi-heads from male and female adults, from different ethnic groups. They were fixed in formol, and belong to the Anatomy Laboratory at the Faculty of Dentistry in Araraquara UNESP. These hemi-heads were dissected by lateral access, preserving the buccal nerve in its trajectory related to the anterior margin of the ramus of the mandible until its penetration in the buccinator muscle. Next, we desinserted the masseter muscle so that all the ramus of the mandible were exposed. Then, the following measurements were carried out: from the base of the mandible until the buccal nerve and from the base of the mandible until the apices of the mandibular coronoid process. These measurements were accomplished with a Mitutoyo CD-6" CS digital paquimeter. The following average values were obtained: 32.26 $\mathrm{mm}$ (to the left side) and $32.04 \mathrm{~mm}$ (to the right side), from the base of the mandible until the buccal nerve and $59.09 \mathrm{~mm}$ (to the left side) and $58.95 \mathrm{~mm}$ ( to the right side) from the base of the mandible until the apices of the coronoid process. We have concluded that normally, the buccal nerve crosses the anterior margin of the ramus of the mandible in an area which is above the superior half of the ramus of the mandible and also that the interventions in the retromolar region do not offer great risks of injury in the buccal nerve.
\end{abstract}

\section{KEY WORDS: Buccal nerve; Nerve anatomy; Nerve trajectory; Retromolar area.}

\section{INTRODUCTION}

Undoubtedly, the knowledge of the buccal nerve anatomy is of extreme importance, not only for its anesthesia but also to carry out safe interventions in the retromolar region. Merril (1979) suggests that the branches of the buccal nerve are frequently cut during the incision for the removal of mandibular third molars but sensory changes in the buccal mucosa go unnoticed. MacGregor (1985) appears to support this view.

Initially, the buccal nerve presents an anterior trajectory, expanding between both bundles of the lateral pterygoid muscle. Then it keeps a descendent trajectory next to the medial face of the ramus of the mandible, to finally cross the retromolar trigone in direction to the cheeks (Alves \& Cândido, 2007; 2008).

Sicher \& Dubrul (1991), claim that the buccal nerve crosses the superior part of the retromolar fossa, and it is at this point that it can be reached for the anesthetic block. Although the authors who have dedicated themselves to the study of the buccal nerve anatomy mention the retromolar region, they do not describe in a practical way the relation between this region and the nerve.

The aim of this work was to study the trajectory of the bucal nerve in the area where it is related with the anterior margin of the ramus of mandible, therefore providing important data for a safe surgical intervention in the region.

\section{MATERIAL AND METHOD}

In this study we used 10 hemi-heads (5 right and 5 left) from male and female adults from different ethnic groups. They were fixed in formol and belong to Anatomy Laboratory at the Faculty of Dentistry of Araraquara UNESP. These hemi-heads were dissected by lateral access preserving the buccal nerve in its trajectory related to the anterior margin of the ramus of the mandible until its 
penetration in the buccinator muscle (Fig.1). Next, we desinserted the masseter muscle, so that all the ramus of the mandible could be exposed. Then, the following measurements were carried out: from the base of the

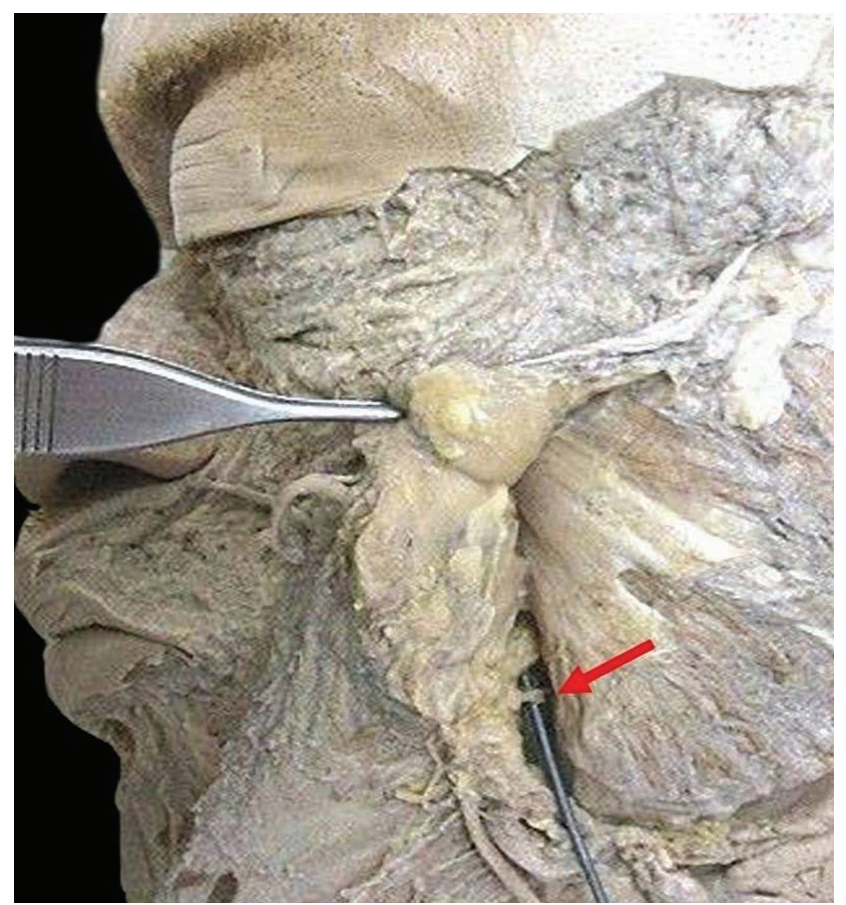

Fig. 1. Buccal nerve penetrating in the buccinator muscle (arrow).

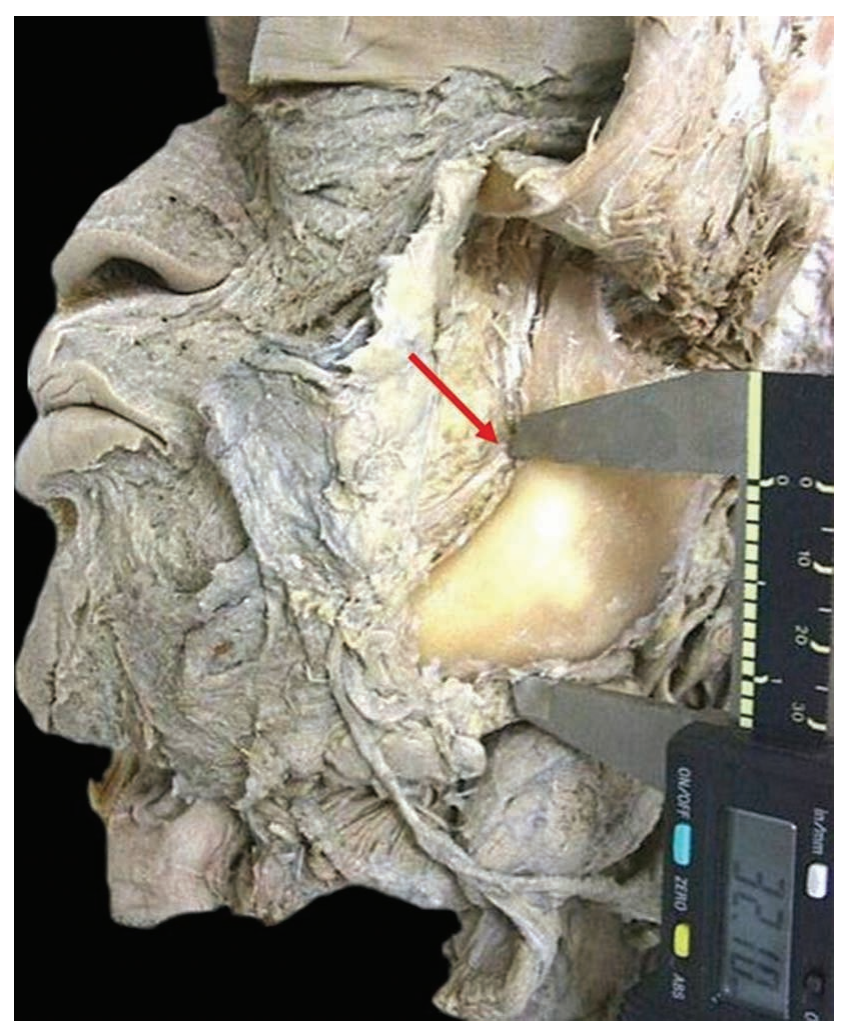

Fig. 2. Measurement from the base of the mandible until the buccal nerve (arrow). mandible until the buccal nerve (Fig. 2) and from the base of the mandible until the apices of the coronoid process. These measurements were done using a Mitutoyo CD-6" CS digital paquimeter.

\section{RESULTS}

The values obtained in the left side hemi-heads are shown in Table I. The average distance obtained from the base of the mandibula until the buccal nerve was of 32.26 $\mathrm{mm}$ and from the base of the mandible until the apices of the coronoid process was of $59.09 \mathrm{~mm}$. The values obtained in the right side hemi-heads are shown in table II.

The average distance obtained from the base of the mandible until the buccal nerve was of $32.04 \mathrm{~mm}$ and from the base of the mandible until the apices of the coronoid process was of $58.95 \mathrm{~mm}$.

Table I. Values obtained in the left side hemi-heads.

\begin{tabular}{ccc}
\hline & $\begin{array}{c}\text { Distance from the base of the } \\
\text { mandible until the buccal } \\
\text { nerve }(\mathrm{mm})\end{array}$ & $\begin{array}{c}\text { Distance from the base of the } \\
\text { mandible until the apices of } \\
\text { the coronoid process }(\mathrm{mm})\end{array}$ \\
\hline 1 & 32.10 & 59.01 \\
2 & 38.02 & 69.30 \\
3 & 31.10 & 56.56 \\
4 & 28.80 & 52.40 \\
5 & 31.30 & 58.20 \\
\hline Average & 32.26 & 59.09 \\
\hline
\end{tabular}

Table II - Values obtained in the right side hemi-heads.

\begin{tabular}{ccc}
\hline & $\begin{array}{c}\text { Distance from the base of } \\
\text { the mandible until the } \\
\text { buccal nerve }(\mathrm{mm})\end{array}$ & $\begin{array}{c}\text { Distance from the base of the } \\
\text { mandible until the apices of the } \\
\text { coronoid process }(\mathrm{mm})\end{array}$ \\
\hline 1 & 32.70 & 60.10 \\
2 & 36.65 & 68.46 \\
3 & 29.85 & 54.51 \\
4 & 30.01 & 54.20 \\
5 & 31.00 & 57.50 \\
Average & 32.04 & 58.95 \\
\hline
\end{tabular}

\section{DISCUSSION}

Although some authors do have suggested that the injury in the buccal nerve, which occurs during incisions for the removal of mandibular third molars are frequent, 
therefore not mentioned (Merril; MacGregor), we do not agree with this statement. Unilateral paresthesia of the buccal sulcus subsequent to trauma to the nerve, would suggest it to be a variation of the buccal nerve.

According to Singh (1981) the only report of postoperative paraesthesia of the buccal sulcus and lower buccal gingiva that was found in literature was related to an aberrant nerve arising from a small foramen in the retromolar fossa. This variation, in which the buccal nerve was thought to arise from the inferior alveolar nerve within the mandible, was also described by Turner (1864).

A similar variation in which both the buccal and mylohioid nerves branched from the inferior alveolar nerve within the mandible and passed through accessory foramina, was found during the dissection of a cadaver of Southern Chinese origin and was reported by Jablonski et al. (1985).

Hendy et al. (1996) concluded that the incisions up to $12 \mathrm{~mm}$ below the greater concavity of the oblique line could result in trauma to the buccal nerve. Taking into consideration that these authors have accomplished their job in edentated individuals, we believe that the oblique line is not a proper parameter to be used, since it is a structure which suffers modifications with the involution of the masticatory device. With the loss of the teeth, the oblique and mylohyoid lines can be situated at the edge level or above it (Alves \& Cândido, 2008) therefore not being structures which are worth of being a reference point. Besides, as being an easily identified structure in patients, we choose to use the anterior margin of the ramus of the mandible as a remarkable point for the descendent trajectory study of the buccal nerve.

In our work we could observe that normally, the buccal nerve crosses the anterior margin of the ramus of the mandible in a region which is above the half of the distance existing between the mandible base and the apices of the coronoid process, so far from the retromolar region, which is where the incisions for the removal of the inferior third molars are carried out.

On average, the bucal nerve crosses the anterior margin of the ramus of the mandible in a region which is above the superior half of the ramus of mandible.

The interventions in the retromolar region do not offer great risks of injury in the buccal nerve.

ALVES, N. Estudio del trayecto descendente del nervio bucal en individuos adultos. Int. J. Morphol., 27(2):295-298, 2009.

RESUMEN: El conocimiento de la anatomía del nervio bucal es de importancia fundamental no sólo para la anestesia, sino también para una intervención segura en la zona retromolar. El objetivo de este trabajo fue estudiar la trayectoria del nervio bucal, en la zona en que se relaciona con el margen anterior de la rama de la mandíbula, proporcionando datos importantes para una intervención segura en la región. En este estudio fueron utilizadas 10 hemi-cabezas de hombres y mujeres adultos, de diferentes grupos étnicos. Las cabezas fueron fijadas en formol, y pertenecen al Laboratorio de Anatomía de la Facultad de Odontología de Araraquara UNESP. Las hemi-cabezas fueron disecadas por medio de un acceso lateral, preservando al nervio bucal en su trayectoria en relación con el margen anterior de la rama de la mandíbula hasta su penetración en el músculo buccinador. A continuación, el músculo masetero fue desinsertado de modo que toda la rama de la mandíbula fue expuesta. A continuación, se llevaron a cabo las siguientes mediciones: desde la base de la mandíbula hasta el nervio bucal y de la base de la mandíbula hasta los ápices de los procesos coronoides mandibular. Estas mediciones se realizaron con un caliper digital CD-6" CS Mitutoyo. Los siguientes valores promedio fueron obtenidos: 32,26 mm (a la izquierda) y $32,04 \mathrm{~mm}$ (a la derecha) de la base de la mandíbula hasta el nervio bucal y 59,09 $\mathrm{mm}$ (a la izquierda) y 58,95 mm (a la derecha) de la base de la mandíbula hasta los ápices de los procesos coronoides. En conclusión, normalmente, el nervio bucal cruza el margen anterior de la rama de la mandíbula en una zona que está por encima de la media superior de la rama de la mandíbula, y también que las intervenciones en la región retromolar no ofrecen grandes riesgos de lesiones en el nervio bucal.

PALABRAS CLAVE: Nervio Bucal; Anatomía nerviosa; Trayectoria de los nervios; Zona retromolar.

\section{REFERENCES}

Alves, N. \& Cândido, P. L. Anatomia para o cuso de Odontologia geral e específica. $1^{\mathrm{a}}$ ed. São Paulo, Santos, 2007.

Alves, N. \& Cândido, P. L. Anatomia para o Cirurgião-Dentista. $1^{\text {a }}$ ed. São Paulo, Santos, 2008.
Hendy, C. W.; Smith, K. G. \& Robinson, P. P. Surgical anatomy of the buccal nerve. Br. J. Oral Maxillofac. Surg., 34(5):457-60, 1996.

Jablonski, N. G.; Cheng, C. M.; Cheng, L. C. \& Cheung, H. M. Unusual origins of the buccal and mylohyoid nerves. Oral Surg. Oral Med. Oral Pathol., 60:487-8, 1985. 
MacGregor, A. J. The impacted lower wisdom tooth. New York, Oxford University Press, 1985.

Merrill, R. G. Prevention, treatment, and prognosis for nerve injury related to the difficult impaction. Dent. Clin. North Am., 23:471-88, 1979.

Sicher, H. \& Dubrul, E. L. Anatomia Oral. $8^{\circ}$ ed. São Paulo, Artes Médicas, 1991.

Singh, S. Aberrant buccal nerve encountered at third molar surgery. Oral Surg. Oral Med. Oral Pathol., 52(2):142, 1981.

Turner, W. On Some Variations in the Arrangement of the Nerves of the Human Body. Nat. Hist. Rev., 4:612-7, 1864.
Correspondence to:

Dr. Nilton Alves

Departamento de Morfología

Faculdade de Odontología de Araraquara, UNESP

Rua Humaitá, 1680

CEP: 14.801-903

Araraquara-São Paulo

BRASIL

E-mail: niltonnalves@hotmail.com

Received: 12-09-2008

Accepted: 22-02-2009 